\section{Intersections}

Canadian Journal of Music

Revue canadienne de musique
Intersections CANADIAN JOURAL OF MUSIC
REVUE CANADIENEE DE MUSIOUH

\title{
Ethics and Musical Language: A Gramscian Reading of Dallapiccola's Liriche greche and Their Influence
}

\section{Jamuna Samuel}

Volume 35, numéro 1, 2015

URI : https://id.erudit.org/iderudit/1038947ar

DOI : https://doi.org/10.7202/1038947ar

Aller au sommaire du numéro

Éditeur(s)

Canadian University Music Society / Société de musique des universités canadiennes

ISSN

1911-0146 (imprimé)

1918-512X (numérique)

Découvrir la revue

Citer cet article

Samuel, J. (2015). Ethics and Musical Language: A Gramscian Reading of Dallapiccola's Liriche greche and Their Influence. Intersections, 35(1), 123-153. https://doi.org/10.7202/1038947ar
Résumé de l'article

Luigi Dallapiccola (1904-75), un pionnier du sérialisme et de l'avant-garde ainsi que compositeur de musique engagée, a composé son cycle de chants intitulé Liriche greche en 1942-45 afin d'échapper à l'anxiété de cette période de guerre. On propose d'examiner dans cette oeuvre la rencontre d'une technique, d'une mise en musique d'un texte, et d'un engagement éthique. Cet assemblage a en effet eu un impact sur les plus jeunes compositeurs Berio, Nono et Maderna, qui y ont chacun répondu dans l'après-guerre par leur propre mise en musique de la collection de traductions libres de poésies classiques grecques de Quasimodo (1940), à laquelle avait emprunté Dallapiccola. On y examine par conséquent l'éthique de Quasimodo en plaçant sa poésie et la mise en musique de Dallapiccola dans le cadre des notions de langage et de politiques de Gramsci, théories ayant eu un grand impact chez les compositeurs italiens de l'après-guerre.
Copyright (c) Canadian University Music Society / Société de musique des universités canadiennes, 2016
Ce document est protégé par la loi sur le droit d'auteur. L'utilisation des services d’Érudit (y compris la reproduction) est assujettie à sa politique d'utilisation que vous pouvez consulter en ligne.

https://apropos.erudit.org/fr/usagers/politique-dutilisation/ 


\title{
ETHICS AND MUSICAL LANGUAGE: A GRAMSCIAN READING OF DALLAPICCOLA'S LIRICHE GRECHE AND THEIR INFLUENCE ${ }^{1}$
}

\author{
Jamuna Samuel
}

For me, Italy is first of all a language. The Italian language made Italians because Italy, before being a nation, is first of all a culture spread by a language. ${ }^{2}$

-Umberto Eco

Luigi Dallapiccola definitively brought to conclusion the first, important stage of that long and laborious journey of [twentieth-century] Italian music-begun with

Busoni's ideals and Alfredo Casella's concrete actions-through difficult waters, often tempestuous, but mostly murky. It was Dallapiccola who completed that difficult crossing with courageous determination, contributing, more than every other, to guide Italian music into the heart of Europe. ${ }^{3}$

-Luciano Berio

Luigi Dallapiccola stands as an unparalleled figure in twentieth-century Italian art music, a trailblazer for the post-Second World War avant-garde. Today the composer's legacy lies principally in his introduction of serialism in 1940s Italy. Yet the question of exactly how and why Dallapiccola's compositions influenced later generations remains largely unconsidered. Two of his works from the 1940 s especially resonated among the three most prominent younger composers emerging in the immediate Italian postwar period: Luigi Nono, Luciano Berio, and Bruno Maderna. One was the opera Il prigioniero

1 I am grateful to Susanna Pasticci, Joseph Straus, and the anonymous reviewers of this journal for their constructive comments on this article. I thank the graduate students in my seminars at Stony Brook University, especially in the Spring 2012 semester, for their active participation as I developed this argument. I presented an earlier version of this paper at the 2012 national meeting of the American Musicological Society in New Orleans, and benefited from the reactions of the panel and public.

2 “Per me, l'Italia è prima di tutto una lingua. La lingua italiana ha fatto gli italiani perché l'Italia, prima di essere una nazione, è innanzitutto una cultura veicolata da una lingua." Umberto Eco, as cited and translated from French by Comberiati and Iounes-Vona (2012, 13). Originally appeared as an interview in Le Monde, "L'Italie c'est avant tout une langue," Le Monde Magazine, 18 March 2011. This and all following translations are mine, unless otherwise indicated.

3 "Luigi Dallapiccola ha portato definitivamente a termine la prima, importante tappa di quel lungo e faticoso viaggio della musica italiana-iniziato idealmente da Busoni e concretamente da Alfredo Casella-attraverso acque difficili, spesso, ma il più delle volte limacciose. È stato Dallapiccola a compiere con coraggiosa determinazione quella difficile traversata, contribuendo, più di ogni altro, a condurre la musica italiana nel cuore dell'Europa" (Berio 1997, 67). 
(The Prisoner, 1943-8), experimental both for the musical technique employed and for the psychological drama unfolded (the composer himself wrote the libretto). ${ }^{4}$ Nono responded with a work of homage five years after the older composer's death-an intricate, expressive, and powerful work for six percussionists and live electronics, Con Luigi Dallapiccola (With Luigi Dallapiccola, 1979), based on the main three-note motive from the opera. Berio based his early serial piano variations, Cinque variazioni (Five Variations, 1952), on the same motive, after having studied with Dallapiccola at Tanglewood in the United States. At around the same time, Maderna in his Kranichsteiner Kammerkantate (1953) included a movement that draws on the opening twelve-tone leitmotif from Dallapiccola's opera, however concealed. ${ }^{5}$ It is not surprising that Il prigioniero was so compelling: it held explicit political and ethical meanings and was written in a creative, experimental, though clearly twelve-tone idiom. It also implicitly claimed in various ways, even by its very genre, the great history of opera in Italy-a claim of certain weight in an era in which other Italian composers, such as Ildebrando Pizzetti, were assuming and using that same history for different ends, including fascist propagandistic ones. ${ }^{6}$

The second work of Dallapiccola that similarly swayed the same younger set of Italian composers was his well-known song cycle, and first fully serial composition, Liriche greche (Greek Lyrics, 1942-5), also written during the Second World War.7 Though akin to Il prigioniero in terms of serial technique, this song cycle differs in seeming, at least as far as the topics of the text are concerned, completely non-political and removed from ethical issues. Since the texts deal with love, nature, and beauty, scholars repeatedly point to the work as a representation of the composer's mental escape from wartime anxieties-an explanation the composer himself propagated.

Those were the years in which Europe, surrounded by barbed wire for a long time by then, was increasingly being reduced to a mass of ruins: the sovereign equilibrium that emanated from the Greek Lyrics contributed, at least in some periods, to relieving me in the face of continuous

4 I explore the relationship between the employment of Dallapiccola's twelve-tone technique in his opera Il prigioniero and its dramatic meaning and politics in Samuel (forthcoming). Relatively recently, critics have pointed to inconsistencies and self-consciously "re"-written autobiographical accounts to crack the picture of integrity, courage, and sometimes hagiographic tone that has circulated in Dallapiccola research. Earle (2013) seeks to deconstruct what he deems self-made myths around Dallapiccola's stature. Osmond-Smith $(2008,21-32)$ was the earliest to cast such doubt. Finally, Alberti (2013) highlights the ambiguities in Dallapiccola's early career regarding his political leanings concerning fascism. See also Flamm (2008-10).

5 Christoph Neidhöfer (2011) highlighted the use of the Roelandt "twelve-tone combination," as Dallapiccola termed it, from Il prigioniero in Maderna's work. The Kranichsteiner Kammerkantate consists of four movements, three of which set politically engaged texts: the first is a letter from an anti-fascist man during the Italian War of Resistance who is condemned to death; the second features excerpts from anonymous business letters, discussing the firing of workers; the third stands apart in content in that it is a love letter by Franz Kafka; the fourth sets excerpts from letters by Antonio Gramsci to his wife and sister-in-law.

6 For more context, see Nicolodi (1984), esp. 120-271 and 275-305.

7 Anna Scalfaro (2011) discusses the musical reception of Quasimodo's translations, especially 53-90. See Phipps (2004), Earle (2006), and Alegant (2010). Alegant's analysis builds on an earlier reading of the Sex carmina Alcaei by Eckert (1985). 
imbalances by which our life was conditioned, to help me bear tragic happenings and perhaps to constitute the necessary contrast with the atmosphere of Il prigioniero, at which I was working. ${ }^{8}$

Thus the cycle exists in stark contrast with the angst-ridden, large-scale, overtly political works such as not only Il prigioniero but also two related choral cycles that chronologically frame the opera, Canti di prigionia (Songs of Imprisonment, 1938-41) and Canti di liberazione (Songs of Liberation, 1951-55), together forming a "protest" triptych. 9

In the late 1940s, Berio, Nono, and Maderna each set lyrics from the same poetic collection that Dallapiccola had used. ${ }^{10}$ Gianmario Borio (1997) has pinpointed a clear effect of the Liriche greche on these postwar composers in demonstrating how at least one passage from Dallapiccola's cycle shaped the Darmstadtian modernism evident in their early use of integral serialism. ${ }^{11}$ In addition to the musical-technical element, however, I explore in this article another layer of motivation behind the influence of Dallapiccola's Liriche greche on Berio, Nono, and Maderna: the texts.

The poems belonged to a groundbreaking set of free translations of classic Greek lyrics entitled Lirici greci (Greek Lyric Poets) by Salvatore Quasimodo (1901-68), published in 1940, long before he won the Nobel Prize for Literature in 1959. I argue that Dallapiccola's compositional and text-setting techniques in this song cycle-including serialism-are intimately linked with ethical and political issues, despite the fact that the selected poetic texts address non-political themes exclusively. In fact, the very choice of these particular poetic texts in the context of wartime Italy generates a nexus among an anti-fascist ethical and political stance, Quasimodo's project, and serialism. An investigation of this topic requires a preliminary consideration of Quasimodo's own aesthetics and politics, enabling in turn a retrospective understanding of his translations. Quasimodo's assertions subsequent to their publication that regard the ethical and political role of the artist in society illuminate the views informing his earlier rewritings of the classic lyrics.

Quasimodo's Lirici greci of 1940 represented a literary feat as revolutionary as Dallapiccola's pioneering musical adoption of the twelve-tone technique. In

8 Dallapiccola, liner notes to the recording of Liriche greche issued by CBS (Epic BG 1088) in December 1968. As cited by Ruffini (2002), 162.

9 The first song of the Canti di prigionia embodied Dallapiccola's otherwise unspoken response to Mussolini's announcement of the racial laws in 1938, laws that affected the composer in a tangible way, given that his wife, Laura Coen Luzzatto, was Jewish. The cycle Canti di prigionia set verses by three historical martyrs-Mary Queen of Scots, Boethius, and Girolamo Savonarola-expressing their pleas and faith. It was then followed in 1955 with Canti di liberazione.

10 Bruno Maderna, Tre liriche greche (Three Greek Lyrics), for soprano, choir, and instruments (composed in 1948, published in Milan by Sugarmusic in 2001); Luigi Nono, untitled autograph and sketches of two poetic settings from Lirici greci, for choir and instruments, ca. 1948, preserved at the Archivio Luigi Nono in Venice (to be published by RAI Trade); Luciano Berio, Tre liriche greche, for voice and piano, manuscript (1946-8), missing.

11 Borio focuses in particular on the second song- "Canone perpetuus"- of the third cycle, Sex carmina Alcaei. Neidhöfer (2010) has also explored inter- and intra-generational influences among the composers. Hermann (2010) presented another case of influence. 
fact, the composer attributed his courage in "taking the twelve-tone road" to the inspiration sparked by Quasimodo's boldness: ${ }^{12}$

\begin{abstract}
Already from 1937, at the time of composition of Tre laudi, I had begun to be interested in the melodic possibilities inherent in twelve-tone series; but only with the three booklets of the Liriche greche did I make a more radical decision. Many are the reasons for such a decision ... I limit myself to noting that this decision coincides with my knowledge of the volume Lirici greci, in the translation by Salvatore Quasimodo, published in 1940 by Corrente Publishing House of Milan. The reading of Lirici greci, the poetic rethinking of Salvatore Quasimodo, so essential and free of every residue of that rhetorical and archaeological language that previous translations had made familiar to us, gave me the idea to rethink them in music, and especially melodically. ${ }^{13}$
\end{abstract}

If Dallapiccola's own settings of Quasimodo's translations constitute a form of cultural translation-an interpretation of another text-then the composer's artistic choice appears to exist on a plane similar to that of the poet. These two forms of cultural translations-Quasimodo's from the Greek poems, and Dallapiccola's from verbal text into music-show their creators' strikingly similar ideas concerning the role of language in society, particularly of its ethical and political role in the construction of Italian national identity, as highlighted in the epigraph from Umberto Eco at the beginning of this article. ${ }^{14}$ The relationship between the Italian language, traditionally tied to cultivated elites, and a historically fractured national identity had generated centuries-long debates well before the 1940s. In fascist-dominated Italy, Italian Marxist leader and critical theorist Antonio Gramsci (1891-1937), a linguist by training, addressed these debates with repeated and articulate formulations that affected Quasimodo's own views (Paternostro 2003) and, as a result (I claim), those of Dallapiccola too. A veritable trailblazer himself, especially among anti-fascist intellectuals (up to this day), Gramsci favoured a radically progressive but fully accessible modernist approach in his views of language;

12 Parallels regarding this reliance on modern poetic and/or spoken language to push a composer's technique can be made for the Second Viennese School. For example, Schoenberg's pivotal op. 15, The Book of Hanging Gardens (1909) relies on the language of Stefan George (1868-1933), as do the earlier opp. 10 and 14; Webern's early songs, opp. 2-4, set the same George; his later Georg Trakl (1887-1914) settings, op. 14 and more (sketches), have been argued by Anne Shreffler (1994) to illuminate his compositional language and development and process shortly before adopting the twelve-tone technique.

13 Dallapiccola, "A proposito delle 'Due liriche di Anacreonte”" (1980, 440-1). (Già nel 1937, al tempo della composizione delle Tre laudi, avevo cominciato a interessarmi alle possibilità melodiche insite nelle serie dodecafoniche; ma soltanto coi tre fascicoli delle Liriche greche mi avvenne di prendere una più radicale decisione ... mi limiterò a notare che questa decisione coincide con la mia conoscenza del volume Lirici greci, nella traduzione di Salvatore Quasimodo, pubblicato nel 1940 dalla Casa Editrice Corrente di Milano. La lettura dei Lirici greci, il ripensamento poetico di Salvatore Quasimodo, così essenziale e sfrondato di ogni residuo di quel linguaggio retorico e archeologico cui precedenti "dotte" traduzioni ci avevano abiutati, mi ha suggerito l'idea di ripensarle in musica e soprattutto melodicamente.)

14 At least briefly in the early 1930s, Quasimodo was active in Dallapiccola's Florence, a city famed for its exchange of cultural ideas among literati and artists at that time. 
similarly, Dallapiccola's twelve-tone language is usually described as "accessible" and "melodic" (see, for example, Montecchi 1993, 331). Some Gramsci scholars understand his ideas on language to be at the root of all of his many contributions, having a wide-ranging repercussion on his ideology, including his well-known and far-reaching concept of hegemony (see Lo Piparo 1979; Ives 2004; Ives and Lacorte 2010).

Within both Quasimodo's and Dallapiccola's outputs, the Liriche grecheand with this I mean both the poems and their settings-arguably participate in a larger political and ideological attempt to reclaim, in a Gramscian way, Italian cultural history from fascist propagandistic appropriations. It is then not surprising that in the postwar period Dallapiccola's anti-fascist ideology, in association with his anti-traditional compositional practice, resonated with composers who sympathized with Marxist ideology such as Berio, Nono, and Maderna. They too, like Dallapiccola, found it natural to express their own ethical and political views through serial music; and this even when, as I believe is the case of the Liriche greche, the literary texts appeared, on the surface, non-political.

In this article the words politics and political refer not so much to issues of government, state, or party, but, more broadly, to the view of the active role of the individual within a free society. This meaning overlaps in part with that of ethics and ethical, emphasizing however the public sphere dimension. ${ }^{15}$ The borders of the "political" thus also include a variety of forms of symbolic or covert dissent from totalitarian regimes, extending to artistic practices. The issue of the connections to Marxism of Berio, Nono, and Maderna is complex and continues to be explored and debated. ${ }^{16}$ In exemplifying a particularly intriguing nexus between politics and technique, the case of the Liriche greche illustrates how issues of influence-at least in the case of the most outstanding Italian composer of the mid-twentieth century-are inextricably linked with specific cultural and historical contexts.

\section{Quasimodo, Gramsci, and the Role of Language AND POETRY}

In his 1947 essay "What Is literature?" Jean-Paul Sartre (1947/2001) famously expressed his conviction that a valid artwork must be engaged. "The writer,"

15 Timothy Rommen's $(2007,33)$ writing on Trinidadian gospel music resonates with my approach, starting with the premise that "ethics permeates the creation and reception of musical style, and this is simply because human beings are engaged in these processes." Rommen invokes Jürgen Habermas's (1984) distinction between the ethical and the moral, the former being a private and irrational discourse, the latter a public and rational one, however tenuous a boundary may exist between the two categories $(39-40)$.

16 For a concise definition along these lines, see Dictionary of the Social Sciences, s.v. "Politics." Regarding Berio, see Quaglia (2010); on Nono, see Nanni (2001); finally, for Maderna's broad orientations, see note 5 above: his choice of the four texts for the 1953 Kranichsteiner Kammerkantata, in which the setting of a love letter is framed by those of politically engaged texts (one of them by Gramsci), all linked by recurring melodic fragments from an anti-fascist popular song, shows that, for the composer, the private and the political aspects were inextricably tied (as they were for all four composers discussed in this article). 
he wrote, "a free man addressing free men, has only one subject-freedom" (1349). Sartre claimed that committed prose was the ideal art form, a necessity for his time. Rejecting the idea of poetry (or any non-representational art) that is for art's sake, he demanded the social responsibility of the artist and the intellectual. While Sartre does not speak of music in "What Is Literature?," he does so in a later essay (introducing René Leibowitz's "The Artist and His Conscience"), explaining that politically engaged music is not possible. However, he refers primarily to non-texted music. ${ }^{17}$ The acts of writing and reading themselves were, for Sartre, embodiments, expressions, indeed acts of freedom, the artwork as such embodying a unique "communicat[ion] among freedoms," which should not be tarnished by "alienation or objectification" (Flynn 2013, sec. 6, par. 4-5). Responding to Sartre, Theodor Adorno (1962) contradicted and complicated the French philosopher's notions, proposing instead that any valuable art object is already inherently moral and that intentionally political work falls into the category of mere propaganda. Adorno famously pointed out that no one could, after all, write a good anti-Semitic novel.

Gramsci's position on the role of art lies between those of Sartre and Adorno. He urged Italian artists and intellectuals to engage the proletariat, to enrich and improve their lives, aiming to enable their discourse with traditionally upper tiers of social and political life. Gramsci did not specify that art be committed, autonomous, or popular-he suggested only that it be progressive and accessible without compromising complexity and creative ideals. ${ }^{18}$ Gramsci's views are important to an understanding of Italian anti-fascist writers and artists, including Quasimodo, given his singular role in Italian political and cultural history.

Today Gramsci's legacy lies mainly with his Prison Notebooks (Quaderni dal carcere) written during his long-suffering incarceration at the hands of Mussolini from 1926 until just before his death in 1937. These notebooks were published posthumously, starting in 1947, the same year in which Sartre's essay first appeared. But Gramsci's writings and ideas on politics, hegemony, and culture had begun circulating long before that. From 1913 until his arrest in November 1926, his articles appeared regularly in socialist and communist newspapers, including the Turin socialist weekly Il grido del popolo, the regional edition of the socialist Avanti!, and his own L'ordine nuovo, which began as a socialist weekly until embracing communist positions in 1921. Indeed, it was that political and cultural persona that affected the public's heightened reception of his views in the 1940s and 1950s-including Dallapiccola's and Quasimodo's-in a moment of increasing domestic tension involving the rise of the strongest Communist party in Western Europe, claiming approximately one-third of the general popular vote in the postwar decades.

Though remembered for his political leadership and eventual martyrdom, Gramsci was first an academic who left his native Sardinia to study linguistics

17 See Sartre $(1965,214)$. See also Carroll $(2003,103-15)$.

18 This is most evident in his early support of Futurism in Italy, which he later withdrew. See Gramsci (1985), 46-51. 
in the northern University of Turin. The debates about language, a staple of Italian culture since the Renaissance, still had acute relevance in early twentieth-century Italy, as the new nation struggled to form its identity. This national identity was impeded by low literacy rates and the lack of a single unifying Italian language, because of the fragmentation into regions of spoken dialect. Gramsci pointed to education reform as the key to the empowerment of the proletariat. In particular, a unified language would enable a shared foundation to unite the citizenry and enable a common discourse. In sum, Gramsci believed that, through language, a society could be remade. In this respect, the leader of the Italian Communist Party was similar to his main political rival and eventual persecutor-Benito Mussolini. As scholar Ruth Ben-Ghiat (2001, 7) describes it, in Mussolini's regime "culture was envisioned as an integrative device that would create a shared set of values to bind Italians to the state." Mussolini, who began his career as a socialist, promised to bring social justice to Italy through culture, among other things, and indeed many intellectuals (some of them turning communist after that fall of fascism) believed in his ideas. Gramsci thus operated in a complex political environment in which culture was seen, also by his opponents and persecutors, as a way to enact social change. Ben-Ghiat explains, "Culture served this generation of intellectuals as a compensatory sphere within the fascist state. Through subsidies and lenient censorship laws, the regime made it possible for younger Italians to give voice to their own visions of a fascist modernity" (13). ${ }^{19}$

Gramsci's writing comes in the midst of Mussolini's strategizing around three main visions identified by Ben-Ghiat: to remake man (rifare l'uomo); to reclaim, develop, clean up (bonificare); and finally, to establish a sense of nationalism (nazionalismo) in the population. Gramsci responded to all three of these issues, but especially to that of "remaking man." His aspiration to raise the standards of popular culture conflicted with those in his party who thought that culture should simply cater to the lower classes and not try to elevate its taste. The linguist Gramsci also clashed with his comrades on the issue of how Italian language could and should be unified. His attention went especially to high literature and poetry. "For socialists of his generation," as Geoffrey Nowell-Smith summarizes, "culture largely meant literature and education-which the working class was to make their own, wresting them from the hands of the bourgeoisie" (Gramsci 1985, 13; my emphasis). Calling on intellectuals to believe in the educational potential of the working class, he was angered by assumptions of workers' inability to appreciate beauty, art, and philosophical thinking: "[They] feel offended in their humanity because the slavery of wages and work cuts them off from a world that integrates man's life, that makes it worth living" (38). He made a case for instituting cultural organizations as a way to empower workers and create an even participation among the socioeconomic levels.

19 Thomas Hirschhorn's Gramsci Monument, "a work in public space" in the Bronx, New York (2013), sought to make Gramsci's views on political change relevant to socioeconomic and racial issues in urban America today. 
For Gramsci, this cultural emancipation had to begin with language. A major obstacle to the Italian proletariat's development of intellectual power remained the problem of mastering language in a newly unified country handicapped by widespread illiteracy (at the advent of fascism, it was approximately 27 per cent, dramatically improved from the $70-80$ per cent of previous generations). Gramsci's theory of how the unification of language should come about is expressed in his reaction to the International Communist Party's experimental imposition of a single international language, Esperanto. His categorical stance against it was controversial within the party. Language, he insisted, should involve a bottom-up infiltration, not a top-down imposition. Mastering language was the only way for the working class to authentically and actively participate in national conversations. With respect to a national language and translation among national languages, Gramsci writes, "A great culture can be translated into the language of another great culture, that is to say a great national language with historic richness and complexity, and it can translate any other great culture and can be a worldwide means of expression. But a dialect cannot do this" (Gramsci 1985, 30). ${ }^{20}$

It was after Gramsci's death in 1937, indeed after the end of the war, that Quasimodo advocated similar views, using rhetoric similar to that of the earlier leader, especially in his reference to the imperative to "remake man." Quasimodo translated that call into his own ethical vision, as a call to a specific kind of intellectual-the poet. ${ }^{21}$ Quasimodo's political views, however, were evident long before his overt postwar statements. His translations from Greek poets (Sappho, Alcaeus, Anacreon, and others) were published by the house Edizioni di Corrente; their magazine, Corrente, had just been shut down by Mussolini for anti-fascist activity. These translations were indeed more like rewritings, injecting new life into a long and ongoing tradition of Italian translation of ancient Greek texts, a tradition extending back to the nineteenth century (Leopardi) and that reached up to a couple of contemporary collections immediately preceding and following Quasimodo's book (Romagnoli 1921 and 1932; Valgimigli 1944). But, in Quasimodo's case, the fresh modernism of the language, the pursued poetic licence, and the resulting popularity across the board were unparalleled for an endeavour of its kind. Conflicting reactions among literary critics swirled amongst an already volatile political environment. ${ }^{22}$

Quasimodo's translations, as Gregory Hays (1995) has highlighted, were much freer, compared to those of previous poets. The celebrated poet Giovanni Pascoli had translated the same poems by preserving the original form and metre, in a translation that aimed at being faithful to the original works.

20 Cited in Maas (2010, 97n28). The note refers to Selections from the Prison Notebooks (1971), 325.

21 The issue of art and politics was surely at the forefront of Quasimodo's mind; his brother-inlaw, the writer Elio Vittorini, was behind the first Italian translation and publication of Sartre's "What Is Literature?" in 1948.

22 Scalfaro $(2011,71)$ notes the positive reception among fascist critics, "revealing the constant will of the regime to instrumentalize any type of tradition, even when the taste in which it is manifested is rather distant, as in the case of Quasimodo's versions, from the emphasis and the bombastic attitudes that accompany the displays of fascist members." 
Quasimodo instead aimed at creatively reworking them. ${ }^{23}$ These reworkingswritten during 1936-40 at the height of Mussolini's power-represent a departure from Quasimodo's pioneering work in the hermetic movement, for which he is still well known. In fact, perhaps it was the act of translating the lyrics that led the poet away from the elitism and esotericism of that movement, pushing him into his more public phase, as represented by the 1942 publication of the Poesie nuove (New poems). These, as literary critic Thomas Bergin argues, feature a more irregular syntax: "One might say legato comes to prevail over staccato ... It is not unlikely that this phenomenon is at least in part a product of Quasimodo's intense study of the Greek poets." 24 Less tangible than the above-illustrated freedom is the general aura of distance surrounding Quasimodo's translations of the Greek poets. Several types of distance were at work-chronological, linguistic, and geographical-and at least in matters of language and literal meaning the translations were further than necessary from the originals.

It was that freedom and that distance exploited by the translator Quasimodo that guided Dallapiccola, as he himself acknowledged, to free and distance his own artistic self from his previous modus operandi. ${ }^{25}$ Through the innovative use of serialism, a revolutionary gesture in wartime Italy, Dallapiccola established a distance from tradition, just as Quasimodo negotiated his own from the Greek poets and earlier Italian translators. In his Liriche greche the composer constructed a new artistic object that almost translates, or rewrites, traditional chamber song-distant in time and in musical language from past models. The employment of the twelve-tone technique paralleled the novelty of Quasimodo's translations, in both their complexity and communicativeness, two aspects that the two artists intended to go hand-in-hand.

In a related, striking similarity between the two artists, Quasimodo's translations can also be viewed as fundamentally, comprehensively, Gramscian in ethos and practice. Both artists-Quasimodo and Dallapiccola-aimed at popularizing something - a poetic repertoire in the former case, and a musical technique in the latter one-that initially would have seemed esoteric. Quasimodo took material-classical lyrics-that traditionally had been the domain of the educated bourgeoisie and upper classes, a foundation of the classical high-school education (but previously rendered in archaic, alienating language) and reworked it with great creative licence into an accessible version

23 The following example illustrates such licence (from Hays 1995, 31-32). Pascoli: Afrodite, figlia di Giove, eterna, / trono adorno, piena di vie: ti prego!/ non domar con pene e con crucci, o grande / nume il mio cuore (Aphrodite, daughter of Jove, eternal, / adorned throne, full of means: I pray you! / Do not suppress with sufferings and with distresses, O great / god of my heart). Quasimodo: Immortale Afrodite dal trono fiorito, / figlia di Zeus, tu che intrecci inganni, / ti supplico, o potente, / non piegare l'anima mia / con affanni e con dolore (Immortal Aphrodite of the flowering throne, / daughter of Zeus, you who weave deceits, / I implore you, O powerful, / Do not oppress my spirit / With grief and with pain).

24 Bergin (1990, 2398), who adds, "Although in his versions he did not follow the classical metrical schemes, yet the disciplined patterns of the ancients may have left their mark on his muse. Greek metrics are rarely fragmented or capricious, and one may even say that the nature of Greek verse is hardly hermetic."

25 See above (note 13) the quote from Dallapiccola's "A proposito delle 'Due liriche.” 
in modern Italian. In a similar way, Dallapiccola adopted the Schoenberghian twelve-tone technique and, as is commonly understood, "Italianized" it. Quasimodo's Greek Lyrics, as Gabriele Finzi $(1983,41)$ suggests, "were read probably by a wider public than that which relished the poet's own verses. And," Finzi continues, "to Quasimodo himself the venture had special significance ... They are hardly line-for-line translations. It was his hope to make them living poems, to make the reader feel that he was not reading translations ... one may suspect that even as he was 'making new' the substance of the ancients, the classical originals may, in turn, have left their mark on the translator." In "translating" the twelve-tone technique, Dallapiccola shared a similar communicative impulse through lyricism.

The mixed critical reaction to the publication of Quasimodo's Lirici greci included academics questioning the accuracy of the translations, whereas the more popular press praised their magnetism. But even those who were critical of the philological aspects had to admit the appeal of the results. ${ }^{26}$ In his famous essay "The Poet and the Politician," Quasimodo himself commented proudly on the success of his book by highlighting the social work that even love poems can have in a time of war-a time in which there cannot be an exclusively private language but everything, including abstract poetry, becomes a political act: "Youths then, as I knew, wrote love letters quoting verses of my lyrics while other verses appeared on prison walls, scrawled by political prisoners. In such times did I write verses, did we write poems, to descend, without hope of forgiveness, into the bitterest solitude ... my readers were still the literati but there must have been others waiting to read my poems. Students, clerks, workers? Had I sought abstract verisimilitudes? The grossest of presumptions? On the contrary, my case exemplified how solitude can be broken" (Quasimodo 1964b, 36).

Quasimodo further articulated the relationship between poetry and politics as one between the poet and the politician. This relationship, he explains, is mediated by a need for order that is internal for the former and external for the latter, and that it is realized during particular historical contingencies: "Can there be any coordination between politician and poet? Possibly where there are societies in process of formation, but never on the plane of absolute freedom. In the contemporary world the politician assumes various aspects, but an accord with the poet will never be possible, since the one concerns himself with the internal order of man and the other with the [external] ordering of men. In a given historical period the internal order of man may coincide with a desire to order and construct a new society" (Quasimodo 1964b, 40).

In the same essay Quasimodo also contrasted the predicament of the prosewriter-who may be corrupted by the politician and made to serve him-with that of the poet, who is entrusted the role of "remaking man." The poet, as Rocco Paternostro has highlighted, participates "in the formation of society of which he was a necessary individuality" (Paternostro 2003, 258-9).

26 Scalfaro $(2011,71)$ cites Paoli $(1940)$. 
Quasimodo's idea of the function of poetic language-sophisticated and at the same time communicative-parallels Dallapiccola's idea of the function of musical language. The composer considered his adoption of the twelve-tone technique as a complex but accessible tool to convey verbal meanings. But this choice was not only a musical one. It was also an ethical one through which music could fulfil an implicit socio-political role if joined with verbal language (that is, with poetry), even regardless of the content of the text. It was the act itself of setting poetry into music - as much as for Quasimodo was the one of making poetry-that had an inherent ethical and political value and that, for Dallapiccola, elevated the twelve-tone technique to something more than a technical device.

What, then, motivated Dallapiccola's choice of setting Quasimodo's Lirici greci within that particular political climate represented by fascist Italy was not the Sartrian idea of "engagement," nor the Adornian one of an inherent ethical choice, nor the aim of conveying the specific political message of the words set to music (as in the composer's own opera The Prisoner, for which he himself wrote the libretto). His inner motivation resided, as it did for Quasimodo, in the Gramscian view of the role played in society by the intellectual/ artist through the use of the Italian language. For postwar composers such as Nono, Maderna, and Berio-who all set poems from Quasimodo's collection using the twelve-tone technique pioneered by Dallapiccola-this ethical-political heritage, which only texted music could fully enable, represented a strong element of attraction to the music of their trailblazer.

\section{Dallapiccola: Text-Setting and Serialist Techniques as Ethical and Political Choices}

In an article that uses Dallapiccola's works as an intriguing case study, Charles Maier and Karen Painter investigate the complex and continuously debated issue of how the fascist regime shaped musical composition in Italy. In a carefully balanced view, they wonder whether it is possible to "talk about any consistent impact that fascist ideology had on serious musical composition." They discuss how musical forms, genres, and even scoring could indeed be understood as representing politics under the fascist regime, and note that "despite official ideology, even under would-be totalitarian regimes, the agenda of artists and critics can never be totally politicized" (Maier and Painter 2004, 567). ${ }^{27}$ At the same time, they question if such an agenda can ever be totally depoliticized, and thus invoke the illuminating concept of "inner emigration" to aptly describe Dallapiccola's necessarily unspoken positions, recalling the Manifesto of Ten (Manifesto dei Dieci) from 1932 signed by critics of atonal music, who pitted such a modernist move against Italian fascist patriotism. ${ }^{28}$ Dallapiccola

27 Rommen (2007, 90-1) describes a similar phenomenon among Trinidadian Full Gospel believers, who, through singing North American music, "imaginatively plac[e] themselves outside of (far from) home ... effectively able to erase (or at least deflect) their own difficulties with regard to the racial imagination and cultural politics in Trinidad."

28 The Manifesto di musicisti italiani per la tradizione dell'arte romantica dell'ottocento included among its signatories Ottorino Respighi and Ildebrando Pizzetti, both of whom were aligned with the 
never responded verbally to this manifesto, but his music from the late $1930 \mathrm{~s}$ on functions as his implicit response. The "inner emigration" highlighted by Maier and Painter, I argue, can be perceived, however unspoken, also in a work like the Liriche greche, perhaps better than in any of the more overtly political compositions, such as Il prigioniero.

Dallapiccola was not the only composer setting these lyrics, as mentioned at the beginning of this article. Anna Scalfaro has discussed the impact that Quasimodo's translations had among fourteen Italian composers from 1940 to 1960 alone. ${ }^{29}$ However varied these settings, she observes, their musical style was modernist, thereby resisting the predominant neoclassicist conservatism more tied to the fascist regime..$^{30}$ Scalfaro, however, refrains from discussing any political ramifications of the poems or the settings. Similarly, Borio, who was the first to investigate the influence of Dallapiccola's Liriche greche, discusses technique only, highlighting their role as a bridge from the second Viennese school to the postwar integral serialism of Berio, Nono, and Maderna (Borio 1997). But, as Emiliano Ricciardi (2007) has noticed, though several other notable Italian composers of Dallapiccola's generation also experimented with dodecaphonic music, they did not wield the same postwar influence. ${ }^{31}$ Ricciardi problematizes what he considers an exaggerated heroic isolation of Dallapiccola, pointing out that "a deep commitment to dodecaphony was not the atypical experience of one individual, but rather a much wider phenomenon that can be read against the background of specific tendencies in Italian culture of the time" (5). Still, as I argue by invoking a common Gramscian linguistic background, something did set Dallapiccola's choice of Quasimodo's translations apart and made his adoption of the serial technique, as associated with these texts, extremely influential on postwar composers.

In his output preceding and contemporaneous with Liriche greche, the composer had been crafting works that were both "engaged" (in the Sartrian way) and not. His explicitly political works include, as mentioned, the choral cycle Canti di prigionia, written in response to Mussolini's 1938 racial laws, and the opera Il prigioniero, an angst-ridden drama inspired by the composer's own crises in occupied Florence. At the other extreme, Dallapiccola wrote absolute instrumental works such as the experimental Divertimento in quattro esercizi (Divertimento in four exercises, 1934) and the sparkling Musica per tre pianoforti (Music for three pianos, 1935). This seeming dichotomy in attributing meanings to music-either as an autonomous aesthetic object or as a fully committed political/ethical statement-might be accepted as reflecting mutually exclusive categories. Yet the Liriche greche calls this dichotomy into question, because of the novelty in Italy of using the twelve-tone technique and of attributing an extra-musical value to it-more precisely, an ethical one-in conjunction with a verbal text. When Dallapiccola first heard the twelve-tone

government. See Zanetti $(1985,1623-4)$.

29 Scalfaro $(2011,16)$ discusses settings by Petrassi, Caltabiano, Prosperi, Dallapiccola, Maderna, Nono, de Angelis, Chailly, and mentions those by Bussotti and Berio.

30 See, for example, Nicolodi $(1984,32-54)$.

31 Ricciardi discusses Roman Vlad and Camillo Togni, among other important figures. 
music of Anton Webern, he wrote that though he did not grasp it as music in itself, he perceived the composer's morality in it:

I had noticed for a while how dodecaphonic music was not difficult to understand because it contained, for example, many dissonances. This appeared clear to me already in 1935 when, in Prague, at the thirteenth festival of the International Society of Contemporary Music, I had the fortune to hear the Concerto op. 24 of Anton Webern, that I applauded because in it appeared to me the highest morality of the composer; not because I had understood it as far as it was music. It seemed to me already then evident how the difficulty of comprehension of such music resided elsewhere and, especially, in a new dialectic. ${ }^{2}$

The originality of the Liriche greche, however, was in their use of the serial technique in conjunction with a vocal setting, revealing Dallapiccola's ethical and political inclinations in ways that I defined above as Gramscian. The use of solo voice, as Maier and Painter discuss, held a particular meaning in a time when a struggle over the "politics of voice" was at play in fascist Italy (Maier and Painter 2004, 581-8). Just before writing the Liriche greche, the composer reflected on the use of human voice: "Vocality should be re-begun after the Schumannian-Wagnerian-Brahmsian non-polyphony. Perhaps reconnecting it to the writing of the Flemish masters." 33 This seemingly neutral statement on vocality gains importance in the context of the general Gramscian view of a renewal of language, sketched above in connection with Quasimodo. Maier and Painter rightly relate the issue of the politics of voice to the overtly political works by Dallapiccola-Volo di notte, Canti di prigionia, and Il prigionieromaking a case for "a struggle over the meaning of voice" between fascist musical traditionalists and those promoting international modernism, and asking what purposes voice served (Maier and Painter 2004, 581-2). In a reading that can extend to the Liriche greche, they claim that Dallapiccola asserted his own dissenting views through his use of voice, but "the dissent was never social or conventionally political: it was an affirmation of the private and religious self, to be achieved through the continued purification of musical sound" (586).

Finally, another indirect political implication that the Liriche greche had in fascist Italy was its use of a small and varying instrumental ensemble in conjunction with serialist techniques, since this practice pointed to those of the second Viennese school. As Fiamma Nicolodi among many has highlighted, in fascist Italy there was the clear perception that performing Schoenberg's music

32 "Avevo notato già da tempo come la musica dodecafonica non fosse difficile a esser compresa perché conteneva, ad esempio, tante dissonanze. Questo mi era apparso chiaro già nel 1935, quando, a Praga, al XIII Festival della Società Internazionale di Musica Contemporanea, ebbi la ventura di udire il Concerto op. 24 di Anton Webern, che applaudii perché in esso mi apparve la morale altissima del compositore; non perché l'avessi compreso in quanto musica. Mi apparve già allora evidente come la difficoltà di comprensione di tale musica risiedesse altrove e, soprattutto, nella nuova dialettica" (Dallapiccola 1980, 453). Cooke $(1951,323)$ offers a different translation.

33 Dallapiccola to Massimo Mila, 11 March 1941: "La vocalità andava ricominciata dopo la nonpolifonia schumanniana wagneriana brahmsiana. Magari riattaccandosi alla scrittura dei maestri fiamminghi” (Aragona 2005, 38). 
was oppositional to the regime, not least because his music was promoted by anti-fascist intellectuals such as Luigi Rognoni in Milan (Ricciardi 2007, 34-8). In this respect, the Liriche greche also embodied a coexistence of nationalist pride (but one not associated with the regime) with larger internationalist aspirations. These trends were often in conflict but both were necessary for the Italian cultural players to build a sense of their own identity. ${ }^{34}$ Italian intellectuals, who had developed a complex of inferiority with respect to their European cultural colleagues oltralpe essentially from the time of the nation's unification on, aspired to both absorb the best of foreign trends and establish their own national identity. Fascist opinions complicated this effort, with their commitment to developing national culture and glorification of Italy's past and using it for propaganda purposes.

Maier and Painter note how, during the years of fascism, many musical decisions were politically charged, observing the "often ambiguous receptivity to modern music" by the influential figure Alfredo Casella, who supported fascism. They contrast Casella with Dallapiccola, who, "recognized as full of promise by [Casella], embarked on a more venturesome, though curiously hermetic aesthetic and personal path with greater political risks," citing the example of "the Viennese combination of solo soprano (assigned ever more daring vocal leaps) and chamber ensemble [that] steered between the traditionalists' paeans to opera and Casella's hopes for a revival of instrumental music." However nuanced and complicated the differences and tensions between Casella and Dallapiccola, Maier and Painter insist on placing them on the same ideological side, in that "neither of these men spoke for a return to tradition or the defense of Italian musical achievement as did the ten signators (Ottorino Respighi and Ildebrando Pizzetti among them) of the December 1932 manifesto," which attacked musical modernism. Indeed, Casella was one of the clear targets of the manifesto $(2004,571-2)$.

Dallapiccola's choice of setting Quasimodo's translations, as well as that of using the twelve-tone technique, can thus be situated in this wider political context. Quasimodo's poetic texts-fresh, modern translations of ancient Greek poetry-had resonated strongly, as we remember, among the Italian public. Despite the anti-fascist alliances of the author, they ended up being praised even from Fascist critics, "revealing," as Scalfaro $(2011,71)$ claims, "the constant will of the regime to instrumentalize any type of tradition, even when it manifests a taste that is rather distant, as in the case of Quasimodo's versions, from the emphasis and the bombastic attitudes that accompany the shows of fascist unions." Dallapiccola's choice of Quasimodo's translations gain, in this respect, even further significance in light of the fact that over two-thirds of the composer's output was texted, including all of his compositions up to 1941, when he completed two instrumental works that, however, reverted to a tonal, neoclassical style, straying from his steady path toward twelve-tone writing that had characterized his texted compositions of the time. The Liriche greche

34 As discussed, for example, by Ben-Ghiat (2001, 17-37). 
interrupted this regressive phase, in this respect overlapping with the protest opera Il prigioniero, which, as mentioned, also uses serialist techniques.

The importance of text to Dallapiccola's composition and evolution, especially for his twelve-tone works in the 1940s and 1950s, shows a profound affinity with the idea shared by Gramsci and Quasimodo that verbal language is an essential component of art and has a political impact on society. For Dallapiccola, art can be simple and communicative-lyrical and emotional (as it is often acknowledged by critics) - while also technically complex and challenging, as his use of serialism shows. Creating art, for the composer, was an ethical imperative that is reflected in that "internal order," as Quasimodo put it, that music can achieve through the adoption of the serial technique. At the same time this "internal order" reflects, again as in Quasimodo, an ethically and politically effective message about the role of the individual in society, as Dallapiccola shows by composing, in the same period of his Liriche greche, works that are today seen as "protest works," like the Canti di liberazione and Il prigioniero, both representing a clear reaction against the fascist dictatorship and both using the twelve-tone technique. By adopting the Gramscian view discussed above-one inflected towards the views of Quasimodo about the role of the poet, which Dallapiccola absorbs into that of the text-oriented composer-the Liriche greche appear to embody an ethical and political message, despite their non-political literal topics of love, nature, and beauty. It is to this message that composers of the postwar generation like Berio, Nono, and Maderna responded, likely intrigued, as we are today, by the fascinating mix of technical complexity and lyrical communicativeness that characterizes this song cycle.

Dallapiccola's Liriche greche consist of three cycles: Cinque frammenti di Saffo (Five fragments of Sappho), Due liriche di Anacreonte (Two lyrics of Anacreon), and Sex carmina Alcaei (Six carminas by Alcaeus). After completing his politically charged Canti di prigionia, in 1942 the composer began working on the Liriche, at the same time that his music was banned by the Nazis in Germany. He met Webern in Vienna, and the following year he dedicated the third and last cycle of the Liriche greche, entitled Sex carmina Alcaei, to him. Between 1943 and 1944, after having drafted the libretto for his protest opera Il prigioniero, he was evacuated to a hiding place outside of Florence, and he began the Due liriche di Anacreonte, eventually completing it the year after and placing it in between the other two cycles. The entire collection was published in 1946.

Examples 1 and $2 \mathrm{a}$ and $2 \mathrm{~b}$ include excerpts from the first and last cycles of Dallapiccola's work. Example 1 shows the simple and technically transparent opening of the Cinque frammenti di Saffo, example 2 a the equally lyrical-but this time monodic-opening of the Sex carmina, and finally example $2 b$ the "Canon perpetuus" from the second song of the same cycle, which then develops in increasing complexity. This path from utmost simplicity to the complexity of serialist and canonic techniques-from the first to the last cycle-can be interpreted as an arch-like large-scale formal element. Dallapiccola himself insisted in a letter to Nono that the song cycle should be performed and understood as 
Traduxione di

SALVATORE QUASIMODO

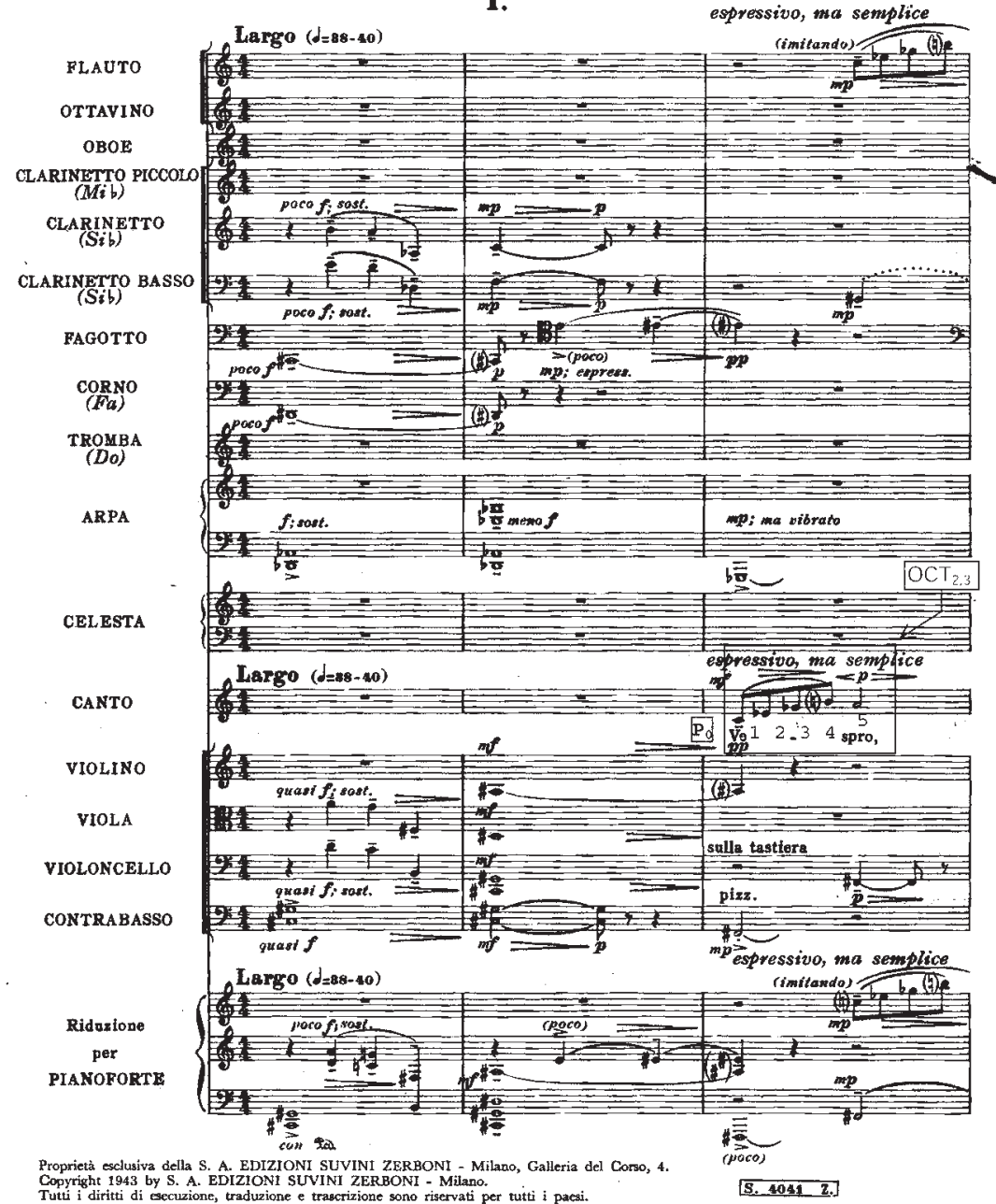

LUIGI DALLAPICCOLA

T.

espressivo, wa semplice 


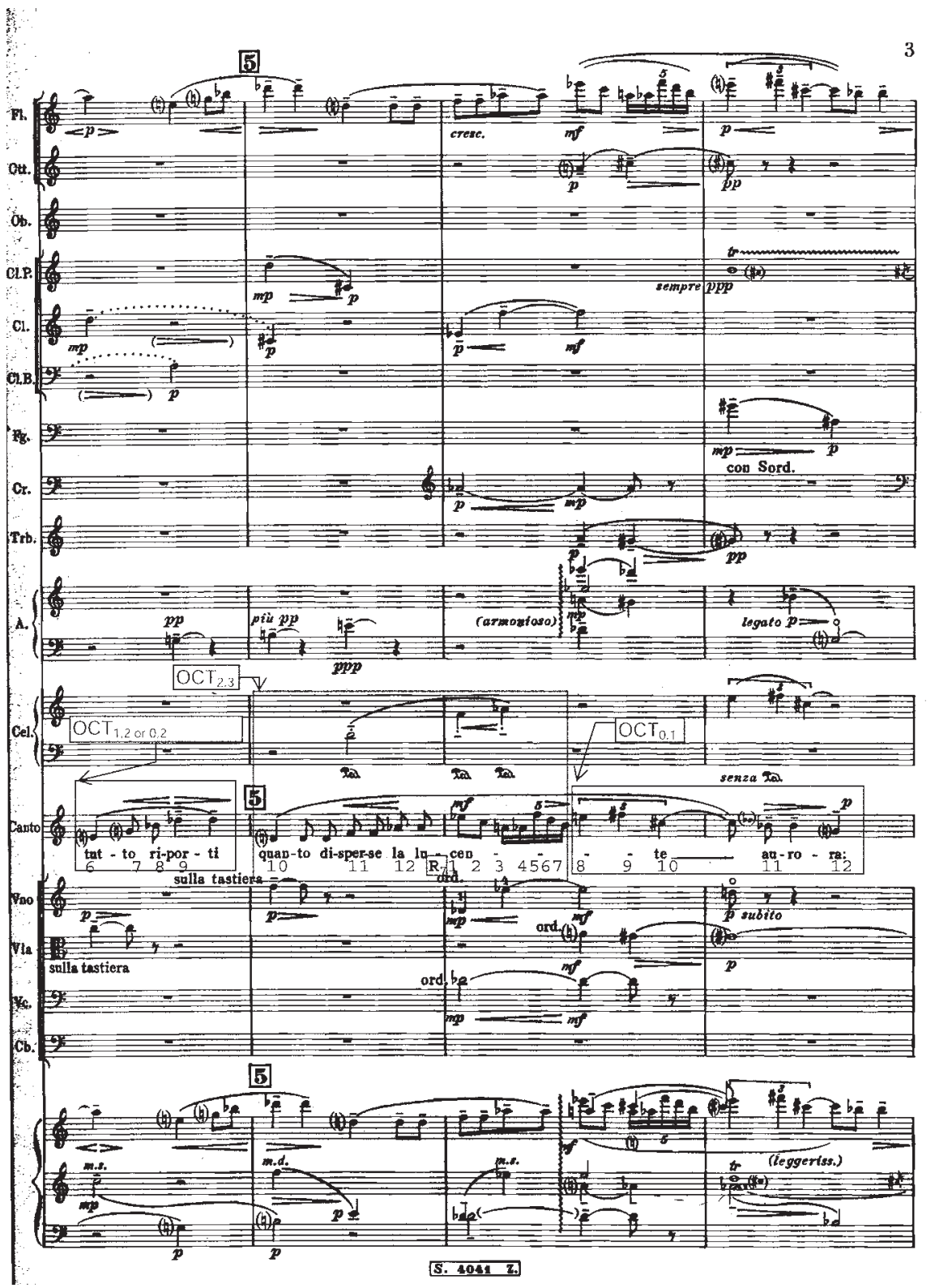

Example 1 (page 2). Opening of "Vespro, tutto riporti," the first song from Luigi Dallapiccola's "Cinque frammenti di Saffo," the first cycle of the three-cycle collection Liriche greche: annotated score. (C) Edizioni Suvini Zerboni - SugarMusic S.p.A., Milano (by kind permission). 
Quest'opera, dedicata ad ANTON WEBERN nel giorno

del suo sessantesimo compleanno ( 3 dicembre 1943),

offro oggi, con umiltà e devozione, alla di Lui memoria.

15 settembre 1945.

\section{SEX CARMINA ALCAEI}

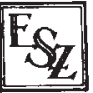

LUIGI DALLA PICCOLA

I. (Expositio)

Molto sostenuto; quasi lento (Tempo rubato) $(d=\mathbf{s e})$

ANTO
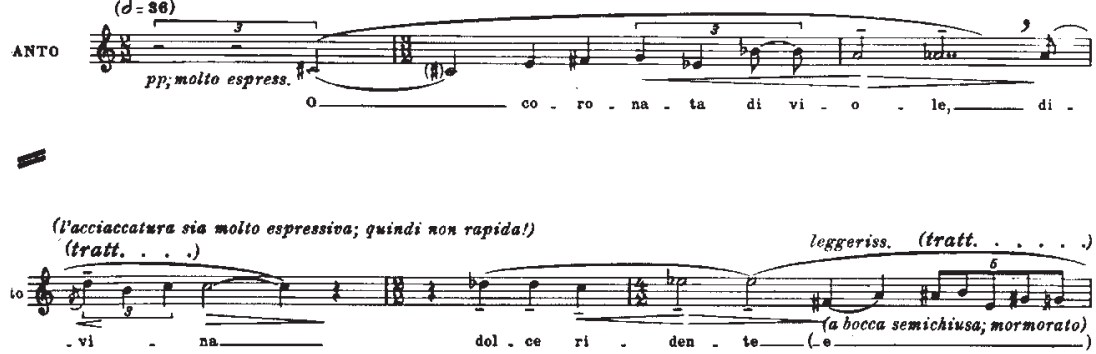

$1]_{(\text {ord })}^{(d=28 ; d \text { della terziza = 84) }}$

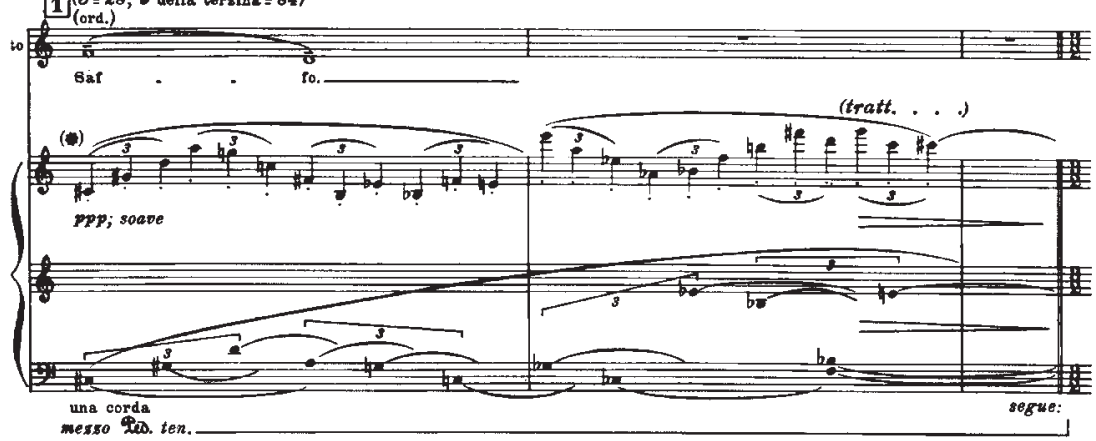

(b) Come un'eco lontanissima. (ctr. L. D.: "CINQUE FRAMMENTI DI SAFFo,;

Example 2a. Complete first song ("Expositio") from Luigi Dallapiccola's "Sex carmina Alcaei," the third and last cycle of Liriche greche (by kind permission). 


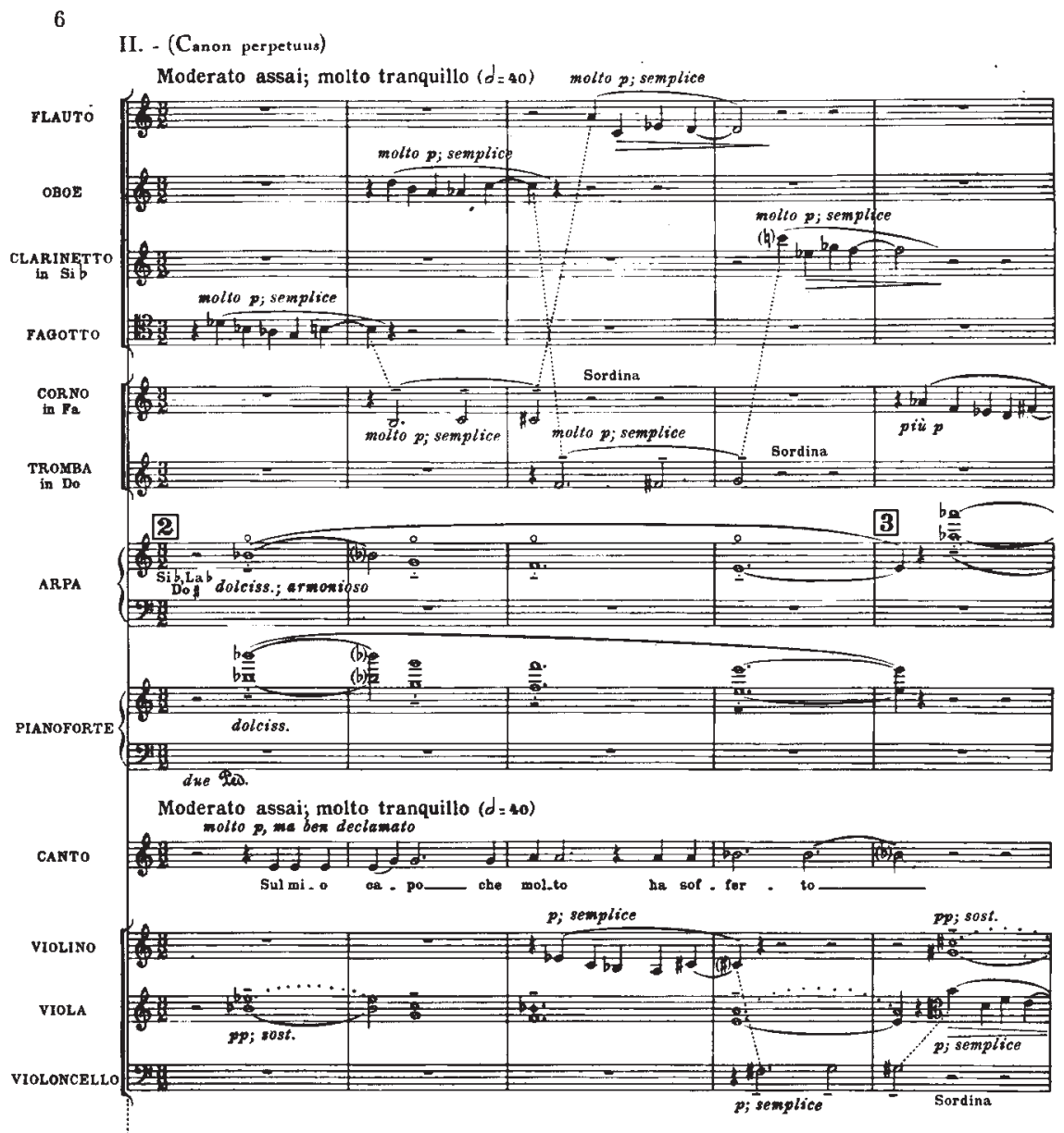

Example 2b. Opening of the second song ("Canon perpetuus") from Luigi Dallapiccola's "Sex carmina Alcaei," the third and last cycle of Liriche greche (by kind permission). 
a whole, not in parts. ${ }^{35}$ In this respect, the cycle can be considered a manifestation of the Gramscian view that art should be both simple and complex, both communicative and artful (in the case of a canon, artificial). Dallapiccola's reordering of the songs into a cycle, from the simplest to the most complex, enables him to lead the listener seamlessly through a gradual evolution and absorption of increasing technical sophistication, without the listener ever being aware of the progressing complexity. Indeed, the musical setting never loses its cantabile and communicative quality (note the indication of semplice in the first four measures of the "Canon perpetuus"). In exemplifying the Gramscian ideal of simultaneous accessibility and avant-garde experimentation, Dallapiccola's musical language parallels that of Quasimodo's Italian transparent language - simple yet elegant, daring yet accessible - both aspiring to an ideal of "classical" simplicity, in both form and expression.

Table 1 shows that, in the first song "Vespro, tutto riporti," the poetic structure transparently guides the musical phrases as defined by the unfolding of the rows. The main syntactical division in the poem, a colon at the end of line 2, coincides with the close of the first two row unfoldings in $\mathrm{m} .7$ (a prime and retrograde form, see annotated score in example 1, which shows the setting of the first two lines of text). Then the third row form sets lines 3 and 4 as a retrograde inversion, while the final climactic line of text, and of music, features an inversion. Both the diatonic and the octatonic underlying organization couch the post-tonal dimension in constant familiar references, tempering potential dissonance with relatively consonant allusions. Octatonic groupings neatly define the row unfolding in the vocal line (see again the annotated score). For example, the first measure in the vocal line of example 1 belongs to OCT2,3; the second measure changes collection, with the following segmentations falling into OCT2,3 and OCTo, $1 .{ }^{36}$ These relatively consonant groupings segment the consecutive unfoldings of complete $\mathrm{P}$ and $\mathrm{R}$ forms of the row. ${ }^{37}$ The text is absorbed into this extremely balanced and tightly crafted musical surface to the point of becoming one with it. This can also be seen, in "Vespro, tutto riporti" (see again example 1), in the madrigalism on "lucente" in mm. 5-6, in the opening fifths pattern that cycles through the aggregate in $\mathrm{mm}$. 1-2 (returning to demarcate line divisions in the middle and at the end of the song), in the clear imitative polyphonic texture in which the flute imitates each vocal gesture at the same pitch and at a distance of two beats, and finally in the evocation of the pastoral world through the sound world created by the clarinet, flute, harp, and celeste.

35 Dallapiccola to Nono, 16 November 1947, as cited by Borio $(1997,359)$.

36 OCT o,1: pitch classes o134679a; OCT1,2: pitch classes 124578ab; OCT2,3: pitch classes 0235689 b. For a brief explanation of octatonic groupings, see Straus $(2005,144)$.

37 Michael Eckert (1985, 35-48, esp. 41-7) identifies other octatonic elements in the Sex carmina Alcaei. 
Table 1.

\begin{tabular}{|c|c|c|c|c|}
\hline Line & Text & Row Form & $\begin{array}{r}\text { Order } \\
\text { Numbers }\end{array}$ & Measure \\
\hline 1 & $\begin{array}{l}\text { Vespro, } \\
\text { tutto riporti } \\
\text { Evening, you bring back everything }\end{array}$ & $P_{0}$ & $1-9$ & $3-4$ \\
\hline 2 & $\begin{array}{l}\text { Quanto disperse la lucente aurora: } \\
\text { That shining dawn dispersed: }\end{array}$ & $\left(P_{0} \rightarrow\right) R_{7}$ & $(10-12) \rightarrow 1-12$ & $5-7$ \\
\hline 3 & $\begin{array}{l}\text { Riporti la pecora, } \\
\text { You bring back the lamb, }\end{array}$ & $\mathrm{RI}_{1}$ & $1-5$ & 10 \\
\hline 4 & $\begin{array}{l}\text { Riporti la capra, } \\
\text { You bring back the goat, }\end{array}$ & $\mathrm{RI}_{1}$ cont'd & $6-9$ & $11-12$ \\
\hline rep. & $\begin{array}{l}\text { Riporti } \\
\text { You bring back }\end{array}$ & $\mathrm{RI}_{1}$ cont'd & $10-12$ & 13 \\
\hline 5 & $\begin{array}{l}\text { Riporti il figlio alla madre. } \\
\text { You bring back the son to the mother. }\end{array}$ & $\mathrm{I}_{4}$ & $1-12$ & $13-16$ \\
\hline
\end{tabular}

Throughout the tripartite cycle, the composer gradually leads the audience through the possible soundscapes of serialism. Whereas in the first cycle (Cinque frammenti) he uses multiple rows per song, and in the second one (Due liriche, consisting of two songs) he employs one row form for each song, in the last cycle (Sex carmina) a single row is adopted for the entire six movements, this being a technically more challenging procedure. Also in this respect, then, throughout the Liriche greche the listener experiences a development from simplicity to complexity.

The Sex carmina Alcaei is characterized by the use of canonic techniques that Dallapiccola, in discussing the Liriche greche, relates to Bach. ${ }^{38}$ But simplicity is recalled right at its beginning. In the first song, marked Expositio (see example 2a), an unaccompanied solo voice unfolds first the prime form of the row and then the retrograde one, with a madrigalism on the final word "ridente" ([sweetly] laughing). At rehearsal number 1, the unfolding fifths recall the opening bars of the very first song of the first cycle (example 1 , see piano reduction on bottom), the original parallel fifths now unfolding linearly. In the second song of the Sex carmina, marked Canon Perpetuus (see example 2b), Dallapiccola reaches, in contrast to the opening movement and the preceding two cycles, a higher degree of complexity and sophistication, indeed

$3^{8}$ Dallapiccola writes in a letter to Maderna:

You speak to me of the Sex carmina Alcaei. Personally I consider this by far the highest work that I have written up until now. This premise is necessary and I promise you that I do it in the most complete good faith. Having established this, which is the problem that I have proposed? To see framed the different emotional states in one of the most difficult musical forms and to apply, wherever I can, to the dodecaphonic system procedures not dissimilar from those that Bach used in no. 3 ("Canones diversi") of the Musical Offering.

(Ella mi parla dei Sex carmina Alcaei. Personalmente considero questo di gran lunga l'opera più alta che finora ho scritto. Questa premessa è necessaria e Le giuro che la faccio nella più completa buona fede. Stabilito questo, quale è il problema che mi sono proposto? Vedere di inquadrare i differenti stati d'animo in una delle più difficili forme musicali e applicare, fin dove posso, al sistema dodecafonico procedimenti non dissimili da quelli che Bach usò nel N. 3, "Canones diversi," dell'Offrande musicale). (Baroni and Dalmonte 1989, 57; cited in Borio 1997, 359). 
foreshadowing pluri-dimensional serialism. This particular song's organization of the dimensions of duration and instrumentation, as Borio has effectively shown, will inspire the successive generation of composers to leap in the direction of integral serialist techniques. In this last song the canonic use of the series is organized into timbral groupings, and a tightly organized rhythm creates an architecture of subtle internal proportions. ${ }^{39}$

In conclusion, in the third and last cycle of the Liriche greche music becomes progressively more autonomous from the text, aiming at almost transcending it. The composer, that is, does not comment or necessarily express the text. This feature of Dallapiccola's text-setting, as we shall see, immediately and permanently struck the young Berio, who went on to set poems from the same Quasimodo collection in the late 1940s, and reflected on these issues in his writings even into the 1990 os.

\section{DAllapiccola's Influence ReVisited}

What is it, then, that made the Liriche greche so appealing to the young generation of postwar composers, at the point that its influence preceded that of clearly politically engaged works such as Il prigioniero or Canti di prigionia? Might it have been precisely the lack of explicit political protest that appealed to the younger composers, who might have viewed the Liriche greche as an implicit statement that everything-however lyrical, however abstract, however individual-can indeed become a political statement? If so, this would have been possible only within a Gramscian view of the role of the composer and of the Italian language. This view, as I have shown, found Dallapiccola aligned with Quasimodo's positions on art and politics, as much as the composer's setting aligns with the poet's words, the music aiming to acquire almost the status of a second language, at replacing text by transcending it. This larger, non-literal statement, made through the Liriche greche, about the role of music, language, and art, would have resonated strongly, especially in the politically charged times of the Italy of the 1940s and 1950s, amidst political regrouping, national reconstruction, and the dramatic rise of the strongest Communist party in the West. 40

It is significant that Bruno Maderna's own settings of Quasimodo's lyrics, for soprano, choir, and instruments, constituted his first important achievement in the adoption of the twelve-tone technique, as much as it was for Dallapiccola. But Maderna, in doing so, went a step further, precisely in that essential aspect that was music's transcending of the text, which Dallapiccola, as we have seen, had accomplished through canonic techniques in the third cycle of his own Liriche greche. When the choir enters in "The Danaides," the second song of his

39 The second movement of the Sex carmina Alcaei features three instrumental groups of three instruments each. They form a triple canon of inversion forms, employing the same rhythmic pattern, each group going through its series three times. A fourth group-the harp and piano-sounds a single series (an inversion) on long values, also following a strict rhythmic model. The voice instead presents a prime form, repeats order numbers at will, and employs varying rhythmic figures $(\mathrm{mm}$. 1-14).

40 The party held anywhere from 20 to 34 per cent of the vote in any given postwar year through the 1980s. See Pasquino (2000). 
cycle (see example 3), the text is not sung but spoken, and Maderna abandons its linear presentation, featuring repeated rhythmic motives corresponding to the repeated textual fragments, whereas chromatic but non-serial music unfolds in the instruments, dominated by percussion (see Conti 2004). The obsessively repeated spoken fragments then dissolve into pure sung vowels, until the soprano voice enters as a solo monody to lyrically declaim the entire second half of the poem-this melodic passage recalling the opening of Dallapiccola's third cycle in example $2 \mathrm{a}$.

Only a few sketches of two settings survive of Luigi Nono's Lirici greci for choir and instruments. ${ }^{41}$ The first song (example 4a) features a lyrical viola monody that recalls the similar vocal opening of the first movement of Dallapiccola's third cycle (example 2a). ${ }^{42}$ This seemingly simple lyrical opening, as Borio has discussed $(1997,363)$, disguises complex preliminary work in which Nono employs different serial techniques, evident in the sketches. Indeed the entire cycle features a similar disguising (or hiding) of the series-a procedure that becomes important in later works of Maderna, Nono, and Berio. ${ }^{43}$ But Nono in his first song, as does Dallapiccola in his first one (example 1), also preserves clarity and communicativeness by aligning a row with each verse or couplet, as shown in example 4b. ${ }^{44}$ As Borio has noted, in Nono's sketches the term rhythmic series appears for the first time, even before Boulez proposed the same concept in his writings. This rhythmic dimension is particularly salient in the second song, having a fragmenting effect on the text, similar to what Maderna had accomplished in his own second song (example 3). From Dallapiccola, Nono assimilated contrapuntal and canonic techniques, but he developed them further, to a point that the linear projection of the text is lost. 45 This is another manifestation of that process of transcending verbal text of which Dallapiccola had shown the path in the Sex carmina Alcaei, and that Maderna also appropriated. In this light, the lyrical solo opening of the viola in example $4 \mathrm{a}$ can be interpreted as the end point of this process, and not as a "purely" instrumental introduction. Nono's fragmentation of the text does not become a betrayal of it, but a refashioning on a different sonic plane. Quasimodo's translations of Greek poetry proved to be extraordinarily suited to this process of abstraction and distancing. They themselves were, as discussed earlier, an abstraction and a distancing from the original Greek works. ${ }^{46}$

41 The critical edition of the score is in progress at RaiTrade. Once made available, the settings should be the earliest of Nono's published compositions. For Maderna instead, the settings come ten years after his first published work (1937) but are, as mentioned, his first twelve-tone work.

42 The excerpt in example $4 \mathrm{a}$ is also published in Borio $(1997,368)$.

43 This well-known tendency of the postwar generation is discussed, for example, by Borio (1997).

44 As shown in example $4 \mathrm{~b}$, in mm. $40-4$ of the manuscript the vocal line setting the first poetic line of text, "Aspettiamo la stella mattutina," unfolds eleven of the twelve pitch classes, with the missing note (F sharp) sustained and trilled in the instruments. Scalfaro $(2011,268)$ mentions this alignment.

45 This is a feature that would come to characterize his choral output, as exemplified in Il canto sospeso, among other works. See Bailey (1992) and Guerrero (2010).

46 Dallapiccola returned the acts of homage in his 1957 cycle Cinque canti, which begins with Jone di Ceo's "Aspettiamo la stella mattutina" (the poem that Nono uses as his first lyric) and con- 

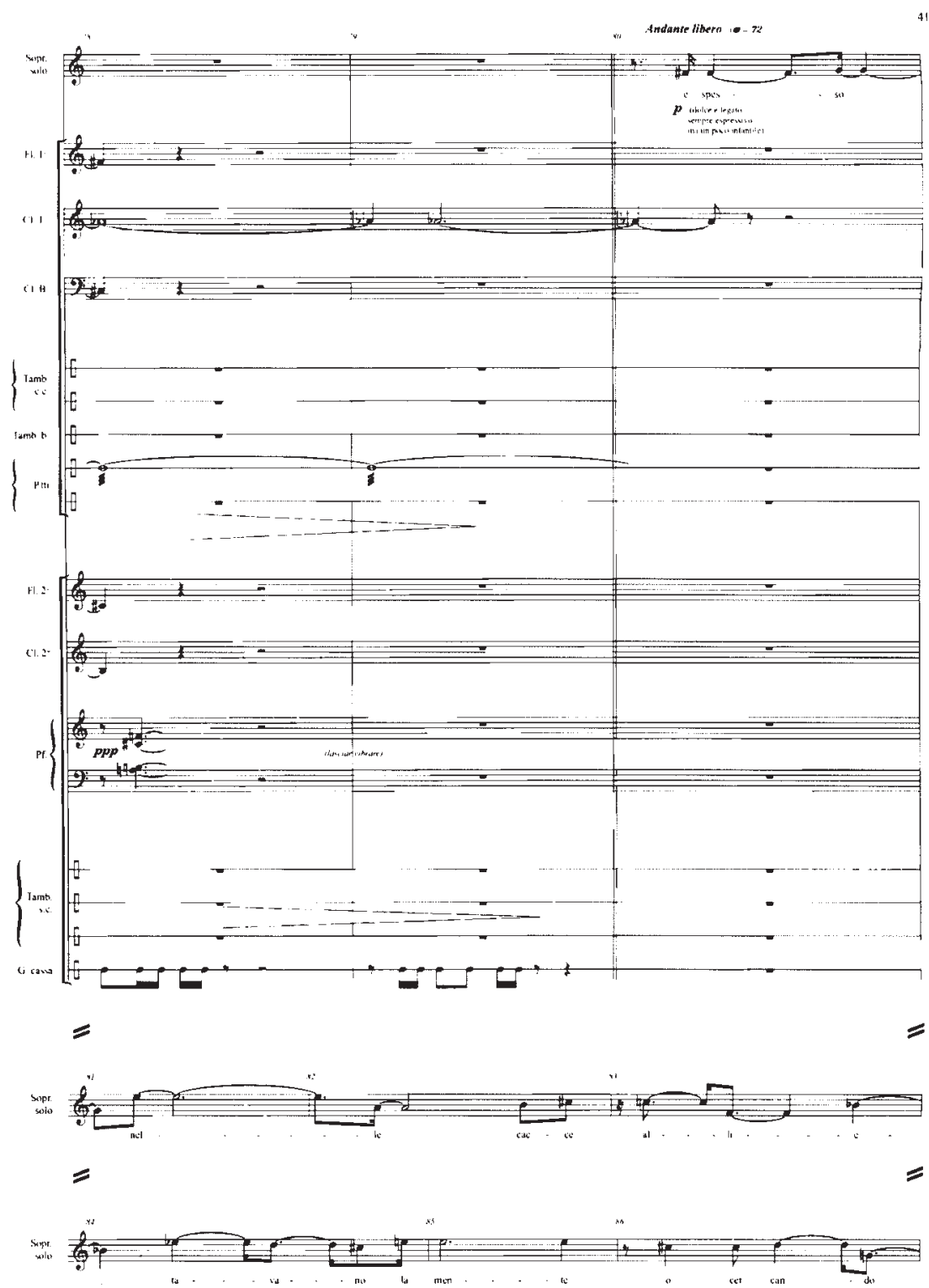

Example 3. Excerpt from “The Danaides," from Bruno Maderna's Tre liriche greche. (C) Edizioni Suvini Zerboni - SugarMusic S.p.A., Milano (by kind permission) 


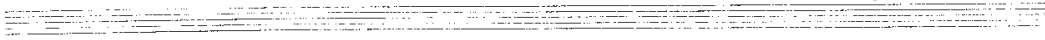

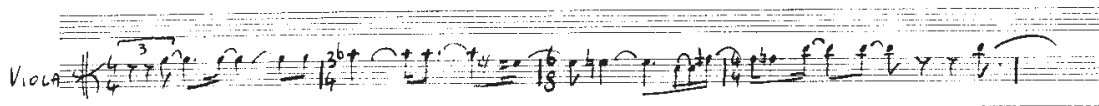

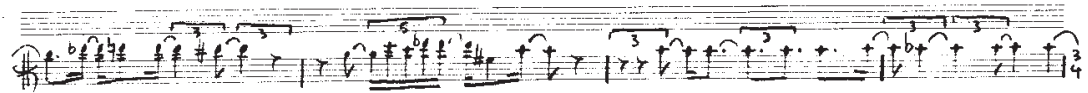

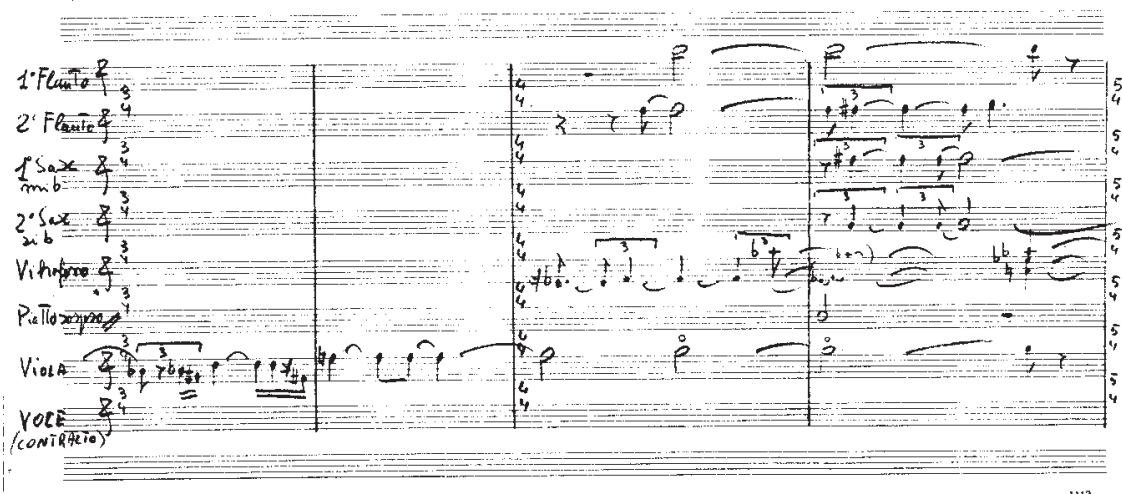

Example 4a. Opening (measures 1-12) of "La stella mattutina," the first song from Luigi Nono's two settings of Quasimodo's Lirici greci. Autograph preserved in catalogue folder Po2.02.02/01-04, Luigi Nono Archive, Venice.

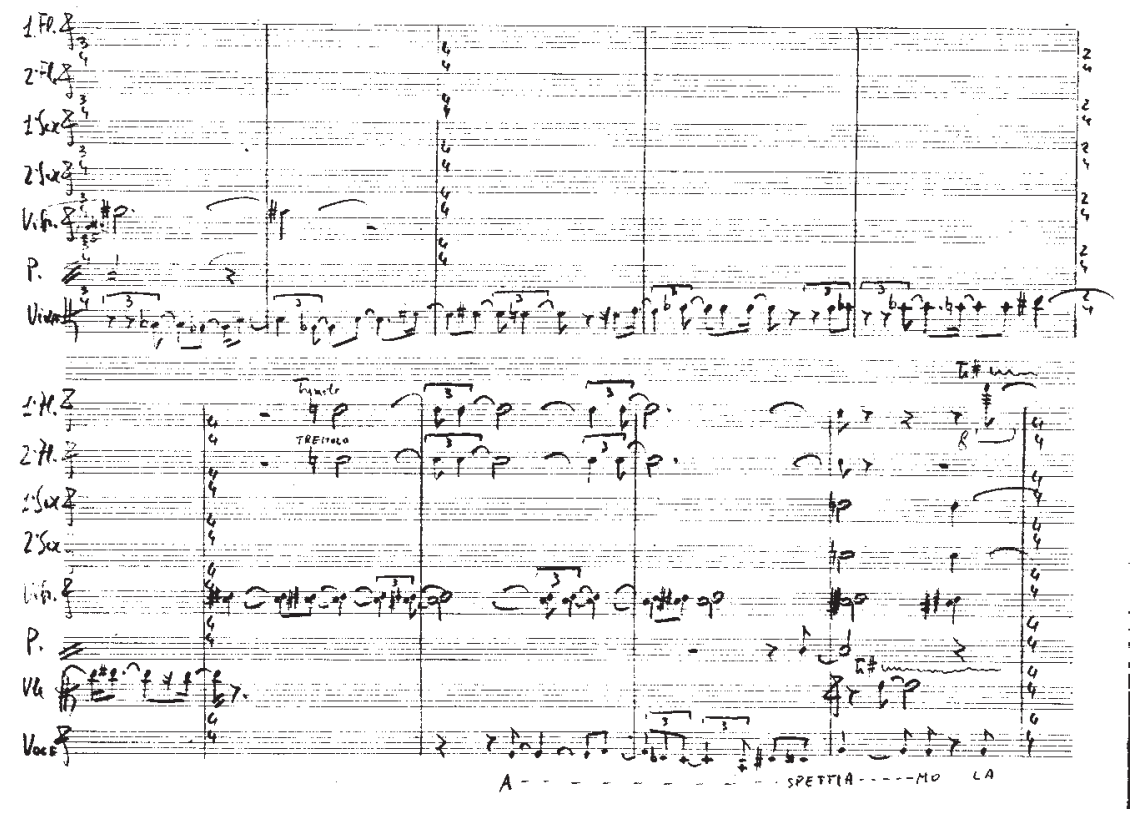

Example 4b (page 1). From Nono, "La stella mattutina," measures 40-44. Autograph preserved in catalog folder Po2.02.02/01-04, Luigi Nono Archive, Venice. 


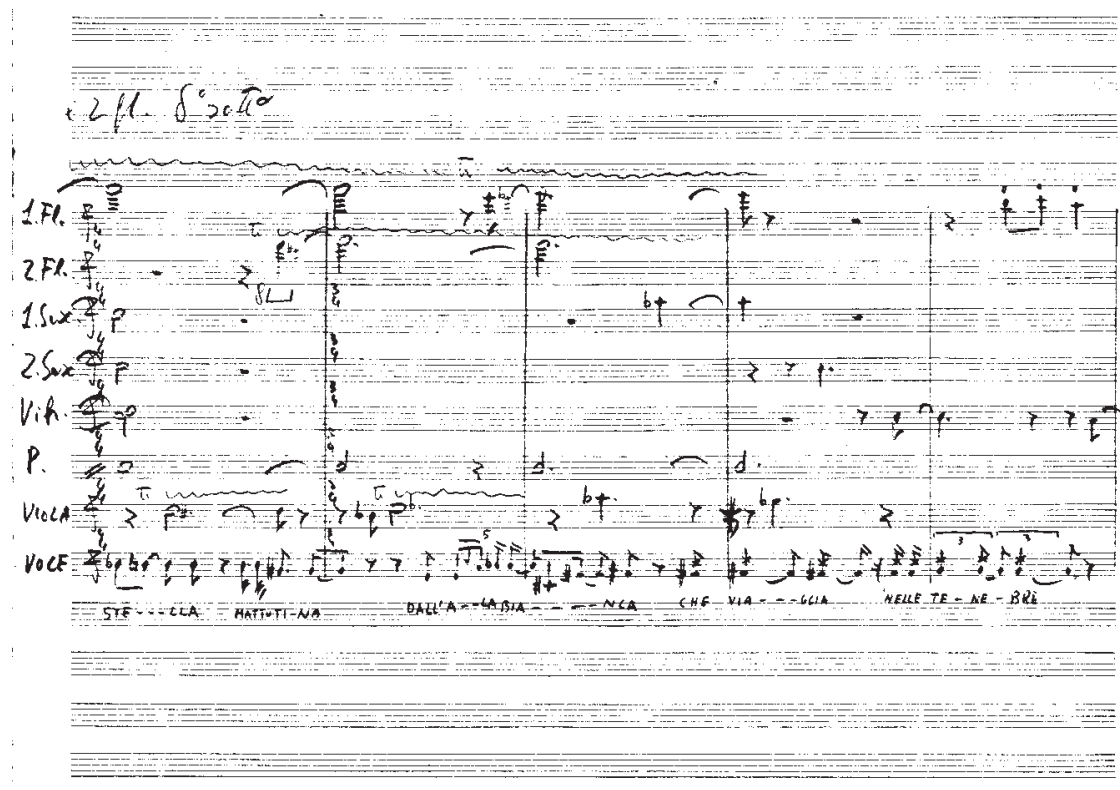

Example 4b (page 2). From Nono, "La stella mattutina," measures 40-44. Autograph preserved in catalog folder Po2.02.02/01-04, Luigi Nono Archive, Venice.

Though the manuscript for Berio's Tre liriche greche for voice and piano remains missing, the composer himself did write insightfully about the legacy of Dallapiccola's vocal music, reflecting precisely what Maderna and Nono inherited in their settings. ${ }^{77}$ Writing in 1990 , Berio $(1997,68)$ claims,

... the vocal music of Dallapiccola is full of this need ... to solidify the text and the music into a structural identity, [i.e.] the voice that sings and the instruments that play .... The music tends to appropriate the text ... and seems to pose questions not just of [the texts], but also of its same way of being with the text: the music surpasses the text until it makes it seem, at times, substitutable ... Dallapiccola manages to position the text in a musical space hypothetically capable of conferring to the text itself a semantic and poetic thickness that it might not otherwise have-as is the case, indeed, of the seductive poetic anecdotes of the Greek lyricists..$^{8}$

tinues on to "Dorati uccelli" (the anonymous poem that Maderna instead uses to start his cycle).

47 In his work Calmo, written in 1974 in memory of Maderna and published in 1989, Berio includes a setting of the same poetic text that Maderna used to open his Tre liriche greche, i.e., "Dorati uccelli." See Berio (1989).

48 ... la musica vocale di Dallapiccola [è] impregnata di questo bisogno ... di saldare in una identità strutturale testo e musica, la voce che canta e gli strumenti che suonano. La musica tende ad appropriarsi del testo ... e sembra porre degli interrogativi non solo ai Lirici greci, ma anche al suo stesso intrinseco modo di essere col testo: la musica supera il testo fino a farcelo apparire, a tratti, sostituibile.... Dallapiccola riesce a collocare il testo in uno spazio musicale ipoteticamente capace di conferire al testo stesso uno spessore semantico e poetico che potrebbe anche non possedere-com'è il caso, appunto, dei seducenti aneddoti poetici dei lirici greci. 
Berio then eloquently characterizes Dallapiccola's influence regarding such transcendence of the text: "Dallapiccola does not 'set a text to music' ... his musical vision does not necessarily interpret a poetic text. It does much more: it invents it. It is a matter, naturally, of virtual invention of the text. It will be in a successive period (we could define it post-Dallapiccolian) that the invention and the re-invention of a text will be real and concrete, when, that is, the specifically phonetic aspects of the language will enter to become part of the musical materials" (Berio 1997, 69).49

What Berio does not mention in this particular passage is that Dallapiccola had opened the path to "the invention and re-invention" of the poetic text in conjunction, or even in symbiosis, with the equally pioneering adoption of the twelve-tone technique. In pursuing the two paths-text-setting and twelve-tone writing - and in showing them as being indeed one, the composer had advanced a larger, ethical-political, Gramscian discourse on the role of the composer as both artist and intellectual, leaving a mark on postwar composers. ${ }^{\circ}$ For Quasimodo, as we have seen, poetry, by reflecting the "internal order" of man, helps in constructing a similar order in society, thus fulfilling the Gramscian ideal that art must have a political role. That order, in Dallapiccola's own compositional practice, is provided by the twelve-tone technique, which Nono, Berio, and Maderna adopted as an ethical imperative. The following excerpt from a speech given by Quasimodo-if read by replacing poet with composer, and poetry with music-encapsulates these composers' ideas concerning the role of art:

Gramsci saw clearly from the darkness of his prison the "literary" principles of the world. The position of the poet cannot be passive in society; he "modifies" the world ... His forceful images, those that he creates, beat on the heart of man more than does philosophy or history. Poetry is transformed into ethic, precisely because of its yield of beauty; its responsibility is in direct proportion to its perfection. To write verses means to undergo judgment; and implicit in the aesthetic judgment are the social reactions to which a poem gives rise ... a poet is a poet when he does not renounce his presence in a given land, at a precise time, politically defined. And poetry is the freedom and truth of that time and not the abstract modulations of sentiment. (Quasimodo 1964a, 26)

In not renouncing "his presence ... at a precise time, politically defined," Dallapiccola initiated a path that Berio, Maderna, and Nono continued, each in his own way, in postwar Italy. In this journey, the Liriche greche played a crucial role.

49 Dallapiccola non 'mette in musica' un testo ... la sua visione musicale non commenta e non interpreta necessariamente un testo poetico. Fa molto di più: se lo inventa. Si tratta, naturalmente, di una invenzione virtuale del testo. Sarà in un periodo successivo (potremmo definirlo post-dallapiccoliano) che l'invenzione e la ri-invenzione di un testo si farà reale e concreta, quando cioè gli aspetti specificatamente fonetici del linguaggio entreranno a far parte dei materiali musicali.

50 Pasticci (2012) explores Berio's ethical vocation. 


\section{REFERENCES}

Adorno, Theodor W. 1979. "On Commitment" (1962), trans. Francis McDonagh. Performing Arts Journal 3 (2): 3-11 and (3): 58-67.

Alberti, Luciano. 2013. La giovinezza sommersa di un compositore. Florence: Olschki.

Alegant, Brian. 2010. The Twelve-Tone Music of Luigi Dallapiccola. Rochester, NY: University of Rochester Press.

Aragona, Livio, ed. 2005. Tempus Aedificandi: Luigi Dallapiccola Massimo Mila Carteggio 1933-75. Milan: Ricordi-Accademia Nazionale di Santa Cecilia.

Bailey, Kathryn. 1992. "Work in Progress: Analyzing Nono's Il Canto Sospeso." Music Analysis 11 (2-3): 279-334.

Baroni, Mario, and Rossana Dalmonte, eds. 1989. Studi su Bruno Maderna. Milan: Suvini Zerboni.

Ben-Ghiat, Ruth. 2001. Fascist Modernities: Italy, 1922-1945. Berkeley: University of California Press.

Bergin, Thomas. 1990. "Salvatore Quasimodo." In European Writers, vol. 12, ed. George Stade, 2387-2411. New York: Charles Scribner's \& Sons.

Berio, Luciano. 1946-8. Tre liriche greche, for voice and piano, manuscript.

—_1989. Calmo. Vienna: Universal Edition. - 1997. "La traversata." In Dallapiccola: Letture e prospettive: Atti del Convegno Internazionale di Studi (Empoli-Firenze, 16-19 febbraio 1995), ed. Mila De Santis, 67-71. Lucca: Ricordi-LIM.

Borio, Gianmario. 1997. "L'influenza di Dallapiccola sui compositori italiani nel secondo dopoguerra." In Dallapiccola: letture e prospettive, ed. Mila De Santis, 357-88. Lucca: Ricordi-LIM.

Carroll, Mark. 2003. Music and Ideology in Cold War Europe. Cambridge: Cambridge University Press, 2003.

Comberiati, Daniele, and Rosaria Iounes-Vona, eds. 2012. Il discorso della nazione nella letteratura italiana: Atti del Convegno Internazionale di Metz (20-21 ottobre 2011). Florence: Cesati.

Conti, Luca. 2004. "Le Tre liriche greche di Maderna e la prima dodecafonia italiana.” In Bruno Maderna: Studi e testimonianze, ed. Rossana Dalmonte and Marco Russo, 275-86. Lucca: LIM.

Cooke, Deryck. 1951. “On the Twelve-Note Road.” Music Survey 4:318-31.

Dallapiccola, Luigi. 1980. Parole e musica. Milan: Il Saggiatore.

Earle, Ben. 2013. Luigi Dallapiccola and Musical Modernism in Fascist Italy. Cambridge: Cambridge University Press.

Earle, Ben. 2006. "Dallapiccola's Early Synthesis: No. 1: 'Vespro, tutti riporti' from Cinque frammenti di Saffo." Music Analysis 25:3-38.

Eckert, Michael. 1985. "Octatonic Elements in the Music of Luigi Dallapiccola." Music Review 46:35-48.

Flynn, Thomas. 2013. "Jean-Paul Sartre." The Stanford Encyclopedia of Philosophy, ed. Edward N. Zalta. http://plato.stanford.edu/archives/fall2013/ entries/sartre/

Flamm, Christoph. 2008-10. "Alcune domande sul significato dei 'Canti di prigionia’ di Luigi Dallapiccola.” Rivista italiana di musicologia 43 (5): 381-93. 
Gramsci, Antonio. 1971. Selections from the Prison Notebooks, ed. and trans. Quintin Hoare and Geoffrey Nowell Smith. New York: International Publishers.

-1985. Selections from the Cultural Writings, ed. David Forgacs and Geoffrey Nowell-Smith, trans. William Boelhower. Cambridge, MA: Harvard University Press.

Guerrero, Jeannie Ma. 2010. "Non-conventional Planar Designs in the Work of Nono and Tintoretto." Music Theory Spectrum 32 (1): 26-43.

Habermas, Jürgen. 1984. The Theory of Communicative Action, vol. 1, trans. Thomas McCarthy. Boston: Beacon.

Hays, Gregory. 1995. “Le Morte Stagioni: Intertextuality in Quasimodo’s Lirici Greci." Forum Italicum 29:26-43.

Hermann, Richard. 2010. "A First Investigation of Berio and Martino as Students of Dallapiccola." Paper presented at the Music Theory Workshop on Italian Serialism, Montreal, April.

Hirschhorn, Thomas. 2013. Gramsci Monument, http://www.diaart.org/gramsci -monument/index.php.

Ives, Peter. 2004. Language and Hegemony in Gramsci. London: Pluto.

Ives, Peter, and Rocco Lacorte, eds. 2010. Gramsci, Language, and Translation. Lanham, MD: Lexingon Books.

Lo Piparo, Franco. 1979. Lingua, intellettuali e egemonia in Gramsci. Bari: Laterza.

Maas, Utz. 2010. "Gramsci the Linguist." In Gramsci, Language, and Translation, ed. Peter Ives and Rocco Lacorte, 81-99. Lanham, MD: Lexington Books.

Maderna, Bruno. Tre liriche greche (Three Greek Lyrics), for soprano, choir, and instruments (composed in 1948, published in Milan by Sugarmusic in 2001)

Maier, Charles, and Karen Painter. 2004. "'Songs of a Prisoner': Luigi Dallapiccola and the Politics of Voice under Fascism," in Italian Music during the Fascist Period, ed. Roberto Illiano, 567-88. Turnhout: Brepols.

Montecchi, Giordano. 1993. "L'itinerario dodecafonico di Luigi Dallapiccola." Rassegna veneta di studi musicali 5-6:331-59.

Nanni, Matteo. 2001. "Luigi Nono: fra impegno politico e prassi estetica. Osservazioni sulla determinabilità del contenuto musicale." In Luigi Nono: Le opere degli anni ' 60 e ' 70 , proceedings of the conference 15-17 November 2001, ed. Archivio Nono, http://static.luiginono.it/atti-convegno-2001/ autori/11ananni.htm.

Neidhöfer, Christoph. 2010. "Multidimensional Serial Techniques of the Italian Avant-Garde: Approaches and Aesthetics." Paper presented at the Music Theory Workshop on Italian Serialism, Montreal, April.

—. 2011. "Compositional Technique as Political Engagement in the Early Serialism of Maderna and Nono." Paper presented at the national meeting of the Society for Music Theory, Minneapolis, 30 October.

Nicolodi, Fiamma. 1984. Musica e musicisti nel ventennio fascista. Fiesole: Discanto. 
Osmond-Smith, David. 2008. "Prove di fede. Appunti sulla formazione ideologica di Luigi Dallapiccola." In Luigi Dallapiccola nel suo secolo, ed Fiamma Nicolodi, 21-32. Florence: Olschki.

Paoli, R. 1940. Review of Lirici greci, in Rivoluzione, 5 September.

Pasquino, Gianfranco. 2000. "Political Development." In Italy since 1945, ed. Patrick McCarthy, 69-94. New York: Oxford University Press.

Pasticci, Susanna. 2012. "In the Meantime, We'll Keep Translating': The Strength of the Ethical Dimension in the Creative Thought of Luciano Berio." In Luciano Berio: Nuove prospettive. Atti del convegno, Siena, Accademia Chigiana, 28-31 ottobre 2008, ed. Angela Ida De Benedictis, 459-75. Florence: Olschki Editore.

Paternostro, Rocco. 2003. "Salvatore Quasimodo o della poesia come etica." Rivista di letteratura italiana 21 (1-2): 251-61.

Phipps, Graham. 2004. "The Classical Italian Vocal Tradition Meets the New Vienna School." In Italian Music during the Fascist Period, ed. Roberto Illiano, 633-56. Turnhout: Brepols.

Quaglia, Bruce. 2010. "Transformation and Becoming Other in the Music and Poetics of Luciano Berio." In Sounding the Virtual: Gilles Deleuze and the Theory and Philosophy of Music, ed. Brian Hulse and Nick Nesbitt, 239-40 (Burlington: Ashgate.

Quasimodo, Salvatore. 1940. Lirici greci [Greek lyric poets], trans. Salvatore Quasimodo. Milan: Edizioni di Corrente.

1964a. "Discourses on Poetry." In The Poet and the Politician, and Other Essays, trans. Thomas G. Bergin and Sergio Pacifici, 3-45. Carbondale: Southern Illinois University Press.

1964b. "The Poet and the Politician." In The Poet and the Politician and Other Essays, trans. Thomas G. Bergin and Sergio Pacifici, 34-45. Carbondale: Southern Illinois University Press.

Ricciardi, Emiliano. 2007. "Twelve-Tone Music and Cultural Life in Italy 1930-

45." MA thesis, University of Cambridge.

Romagnoli, Enrico. 1921. Il libro della poesia greca. Milan: Fratelli Treves.

-1932. I poeti lirici. Bologna: Zanichelli.

Rommen, Timothy. 2007. "Mek Some Noise": Gospel Music and the Ethics of Style in Trinidad. Berkeley-Los Angeles: University of California Press.

Ruffini, Mario. 2002. L'opera di Luigi Dallapiccola: catalogo ragionato. Milan: Sugarmusic.

Samuel, Jamuna. Forthcoming. "Twelve-Tone Serial Techniques in Dallapiccola's The Prisoner as a Reaction to Fascist Ideology." In The Sound of Signs: New Essays on the Role of Semiotics in Opera Analysis, ed. Gregory Decker and Matthew Shaftel. Oxford: Oxford University Press.

Sartre, Jean-Paul. (1947) 2001. "What Is literature?," trans. Bernard Frechtman. In The Norton Anthology of Theory and Criticism, 1336-49. New York: Norton.

. 1965. "The Artist and His Conscience." In Jean-Paul Sartre, Situations, trans. Benita Eisler, 218-19. New York: George Braziller. 
Scalfaro, Anna. 2011. I Lirici greci di Quasimodo: un ventennio di recezione musicale. Rome: Aracne.

Shreffler. 1994. Webern and the Lyric Impulse: Songs and Fragments on Poems of Georg Trakl. Oxford: Oxford University Press.

Straus, Joseph N. 2005. Introduction to Post-Tonal Theory, 3rd ed. Upper Saddle River, NJ: Pearson Prentice Hall.

Valgimigli, Manara. 1944. Saffo e altri lirici greci. Padua: Le Tre Venezie.

Zanetti, Roberto. 1985. La musica italiana nel Novecento. Busto Arsizio: Bramante Editrice.

\begin{abstract}
Luigi Dallapiccola (1904-75) - a pioneering figure as serialist, composer of protest music, and trailblazer for the avant-garde-wrote his Greek Lyrics song cycle (1942-5) as an escape from wartime anxiety. I locate the Lyrics within a nexus of technique, text setting, and ethical engagement. That complex resonated with the younger composers Berio, Nono, and Maderna, each responding in the postwar period with settings from the same collection, Quasimodo's 1940 free translation of classic Greek lyrics. I examine Quasimodo's ethics, placing his poetry and Dallapiccola's settings within Gramsci's notions of language and politics, which were highly influential on postwar Italian composers.
\end{abstract}

\title{
RÉSUMÉ
}

Luigi Dallapiccola (1904-75), un pionnier du sérialisme et de l'avant-garde ainsi que compositeur de musique engagée, a composé son cycle de chants intitulé Liriche greche en 1942-45 afin d'échapper à l'anxiété de cette période de guerre. On propose d'examiner dans cette œuvre la rencontre d'une technique, d'une mise en musique d'un texte, et d'un engagement éthique. Cet assemblage a en effet eu un impact sur les plus jeunes compositeurs Berio, Nono et Maderna, qui y ont chacun répondu dans l'après-guerre par leur propre mise en musique de la collection de traductions libres de poésies classiques grecques de Quasimodo (1940), à laquelle avait emprunté Dallapiccola. On y examine par conséquent l'éthique de Quasimodo en plaçant sa poésie et la mise en musique de Dallapiccola dans le cadre des notions de langage et de politiques de Gramsci, théories ayant eu un grand impact chez les compositeurs italiens de l'après-guerre.

\section{BIOGRAPHY}

Jamuna Samuel (PhD, CUNY) is Mellon fellow and lecturer at the University of Pennsylvania; she previously taught at Stony Brook University and Wellesley College as visiting assistant professor. Publications include those in Rivista di analisi e teoria musicale, Indiana Theory Review, Notes, and forthcoming essays on politics and musical technique in Singing in Signs (Decker and Shaftel, eds), and on listening in Italo Calvino's writing. Her book-in-progress examines Luigi Dallapiccola's influence on later composers. 